\title{
QUEEN'S
UNIVERSITY
BELFAST
}

\section{Distribution of arsenic and risk assessment of activities on a golf course fertilised with arsenic-containing Ascophyllum nodosum seaweed}

O'Neill, A., Sengupta, B., \& Phillips, D. (2014). Distribution of arsenic and risk assessment of activities on a golf course fertilised with arsenic-containing Ascophyllum nodosum seaweed. Science of the Total Environment, 482-483(1), 252-259. https://doi.org/10.1016/j.scitotenv.2014.03.006

\section{Published in:}

Science of the Total Environment

\section{Document Version:}

Peer reviewed version

Queen's University Belfast - Research Portal:

Link to publication record in Queen's University Belfast Research Portal

\section{Publisher rights}

This is the author final version of an article published here: http://www.sciencedirect.com/science/article/pii/S0048969714003362

\section{General rights}

Copyright for the publications made accessible via the Queen's University Belfast Research Portal is retained by the author(s) and / or other copyright owners and it is a condition of accessing these publications that users recognise and abide by the legal requirements associated with these rights.

Take down policy

The Research Portal is Queen's institutional repository that provides access to Queen's research output. Every effort has been made to ensure that content in the Research Portal does not infringe any person's rights, or applicable UK laws. If you discover content in the Research Portal that you believe breaches copyright or violates any law, please contact openaccess@qub.ac.uk. 
1 Distribution of arsenic and risk assessment of activities on a golf course

2 fertilised with arsenic-containing Ascophyllum nodosum seaweed

3 Antonia O’Neill ${ }^{1}$, Bhaskar Sen Gupta ${ }^{1 *}$, Debra H. Phillips ${ }^{1}$

$4{ }^{1}$ Environmental Engineering Research Centre, School of Planning, Architecture and Civil

5 Engineering, Queen's University of Belfast, Belfast, BT9 5AG, Northern Ireland, UK

$6 \quad$ *Corresponding author; bhaskar_sengupta@yahoo.com, Tel: +44 (0)28 9097 4554, Fax: +44

$7 \quad(0) 2890974278$.

8

9 Abstract

The use of seaweed fertilisers in sports green maintenance has become a common practice across the globe due to its image as an "eco-friendly" alternative to chemical fertilisers. The aim of this study was to characterise the risk of human exposure to arsenic (As), via dermal absorption, from golfing activities on a private golf course in the UK, where As contaminated seaweed fertiliser $(\sim 100$ $\mathrm{mg} / \mathrm{kgd}$.wt.) is applied. This was fulfilled by, 1) determining As concentrations in shallow soils with GIS geo-statistical analysis, 2) measuring As concentrations from an on-site borehole groundwater well, and (3) developing a risk assessment calculation for golfing activities based on field and questionnaire data. Total As concentrations in shallow soils were less than the UK threshold for domestic soils, however, frequent and sustained dermal contact between site-users and surface soil attributed to a maximum carcinogenic risk value of $2.75 \times 10^{-4}$, which is in the upper limit of the acceptable risk range. Arsenic concentrations in underlying groundwater exceeded the WHO's permissible drinking water standard, demonstrating the risk of groundwater contamination following the application of seaweed fertiliser to golf course soils. This is the first risk study on dermal As absorption via application of a seaweed fertiliser.

Keywords

Arsenic, seaweed fertiliser, golf course, soil, groundwater, risk characterisation. 


\subsection{Introduction}

Arsenic (As)is present throughout the earth's ecosystems in low concentrations. It is prevalent, however, in aquatic environments as a result of weathering of sub-aquatic rocks (Cai et al. 2002; Andrewes et al. 2004; Rose et al. 2007). It is primarily present as organometallic species, such as arsenobetaine and arsenosugars (Ascar et al. 2008), which are naturally bioaccumulated by marine products (i.e. seaweed) (Castlehouse et al. 2003; Hansen et al. 2003; Andrewes et al. 2004; Caumette et al. 2007; Rose et al. 2007). Inorganic forms of As, such as arsenate, have also been found in seaweed species (Castlehouse et al. 2003; Almela et al. 2006). Inorganic forms of As are considered to be more toxic than organic forms because they are rapidly absorbed and retained by tissues in the body (Agency for Toxic Substances and Disease Registry 2011). Up to $100 \mathrm{mg} / \mathrm{kg}$ dry weight (d.wt.) of As has been observed in brown algae species (Castlehouse et al. 2003; Hansen et al. 2003). Traditionally, seaweed has been used by rural communities as a fertiliser and soil conditioner for many centuries (Castlehouse et al. 2003; Andrewes et al. 2004). In the past few decades, the demand for seaweed fertilisers in horticulture, garden maintenance, sports greens and as animal feed has increased across the globe due to its image as an "eco-friendly" resource (Castlehouse et al. 2003).

Arsenic is a known carcinogen (U.S. Environmental Protection Agency 1988) and has many associated health effects. Acute exposure to As can cause vomiting, abdominal pain and associated diarrhoea. Chronic exposure ranges from dermatological manifestations, such as skin lesions and hyperkeratosis on the soles of feet and palms of hands, to cancer of the skin, lungs, kidneys and bladder (Abernathy et al. 1999; Smith et al. 2002; Halder et al. 2013). Arsenic toxicity is heavily dependent upon both its valence state and speciation (Cai et al. 2002; Macedo et al. 2009). Inorganic As is generally more toxic than organic As, because it is rapidly absorbed and retained by tissues in the body (Agency for Toxic Substances and Disease Registry 2011). Arsenosugars are organic and not currently considered to be acutely toxic to humans (Castlehouse et al. 2003; Hansen et al. 2003). However, it is now known that arsenosugars metabolise in the human body in a similar manner to that 
of inorganic As forms. The organometallic forms reduce in the body (Castlehouse et al. 2003) to dimethylarsinic acid, DMA(V), then to the trivalent DMA(III), which are excreted slowly (Hansen et al. 2003). DMA(III) is more toxic than its pentavalent form, DMA (V); therefore, arsenosugars may pose a risk if dermal absorption occurs(Castlehouse et al. 2003; Andrewes et al. 2004). There is a high degree of ambiguity surrounding organometallic compounds and their associated risk of As exposure. The Joint FAO/WHO Expert Committee on Food Additives recommended that further investigation into the health risks posed by organometallic compounds in marine products was necessary (Joint FAO/WHO Expert Committee on Food additives 2011).

Seaweed horticultural products are currently not subjected to any legislative restrictions within the United Kingdom (UK), Europe or the US (I. Rowland, personal communication, $9^{\text {th }}$ September 2010). Additionally, little information on soils amended with seaweed exists in literature. However, results mainly show that arsenosugars have a tendency to reduce to more toxic forms of As in a soil environment in the few seaweed fertiliser studies that exist (Castlehouse et al. 2003; Andrewes et al. 2004; Feng et al. 2005). Therefore, their application in the environment may pose a risk. A combination of increasing use of seaweed fertilisers in agriculture and horticulture, and the significant lack of guidance and legislation could potentially expose many people to unknown toxic effects of this marine product. The presence of As in golf course soils from seaweed fertiliser application has not yet been studied. However, over the past few decades, As contamination of golf course soils due to the use of As-based pesticides has become a topic of interest (Cai et al. 2002; Feng et al. 2005; Pichler et al. 2008). In general, most studies of As based pesticide application to golf course soils have observed As contamination of underlying groundwater (Cai et al. 2002; Feng et al. 2005). The manufactured herbicide monosodium methyl arsenate (MSMA) for example, uses organic As species as its active ingredient and has been observed to leave a residue in amended soils (Rahman et al. 2012). Although organic As is not toxic to humans, it can change speciation in soil environments to a more toxic inorganic form following a series of chemical processes (Feng et al. 2005; U.S. Environmental Protection Agency 2005, Zeng et al., 2011). Castlehouse et al. (2003) has reported that arsenosugars present in seaweed fertilisers produce monomethylarsonic acid (MMA) and 
dimethylarsinic acid (DMA) as degradation products in soil. However, detailed information on the relative toxicity of MMA and DMA to humans is not available. For example, a total DMA value 700$2600 \mathrm{mg} / \mathrm{kg}$ body weight has been reported as $\mathrm{LD}_{50}(\mathrm{Le}, 2001)$. Experimental results on relative toxicity of DMA (III) and DMA (V) to rat cells have also been reported (Cohen et al., 2002, Arnold et al., 2006, Hirano et al., 2004) in the order, MMA (III), DMA (III)>iAs(III) >iAS(V) > DMA(V), MMA (V), based on $\mathrm{LC}_{50}$ values, where DMA (V) toxicity is lower than that of DMA (III) by a factor of $10^{-3}$ to $10^{-4}$. This has also been supported by similar research data (Cohen et al., 2002).

The aim of this research was to calculate the risk of human exposure to As due to golfing activities on a private golf course in the UK, where As-contaminated seaweed fertiliser $(\sim 100 \mathrm{mg} / \mathrm{kg} \mathrm{d}$. wt As) is applied regularly onto the greens and fairways. For this purpose, total As in the top soil was considered for risk assessment. Since organic forms of As transform to inorganic forms of As over a period of time, total As concentration as a basis of exposure risk would cover the worst case risk scenario. This was fulfilled by 1) determining As concentrations in shallow soils with GIS geostatistical analysis, 2) measuring As concentrations from an on-site borehole groundwater well, which is used occasionally for irrigation and 3) developing a risk assessment calculation for golfing activities on the golf course based on field and questionnaire data. To the best of the author's knowledge, this is the first risk study regarding dermal absorption of As following application of a liquid seaweed fertiliser.

\subsection{Materials and methods}

\subsection{Study site}

The private golf club is situated in the UK. The golf course covers a total area of $335000 \mathrm{~m}^{2}$ and is bordered by public woodlands and a densely populated residential area. The golf course is approximately 30 years old and was built on a section of a large estate that was used for grazing. Much of the course has been top-dressed with sand that was dredged, dried and imported from a nearby lake. The site is underlain by an aquifer, which yields high to moderate flows. An on-site 
borehole well (total depth $95 \mathrm{~m}$ ) is used to irrigate the grounds at times of low precipitation. A previous survey conducted across the UK showed that surface soil at the study site had an elevated As content ( 40 mg/kg), which exceeds the $20 \mathrm{mg} / \mathrm{kg}$ threshold for As in domestic soils in the UK (Environment Agency 2009). It was deduced that the source of As at this site was a result of applying a liquid seaweed fertiliser to the soil for the past five years.

Ascophyllum nodosum, commonly known as knotted wrack, is a brown macro-algae sourced from the coasts of the North Atlantic Ocean. The liquid seaweed fertiliser, from the knotted wrack, has been produced by methods that retain the natural form of the plant. ICP analysis confirmed that the seaweed fertiliser had a total As (tAs) concentration ranging between 43 and $92 \mathrm{mg} / \mathrm{kgd} . w \mathrm{wt}, 6$ to $10 \mathrm{mg} / \mathrm{kg}$ wet weight (w.wt.). The fertiliser has been applied three times a month over a five year period to both fairways and greens, referred to as fertilised areas (FA), which make-up $30 \%$ of the total site area. Over the five year period, on-site golfing activity has continued during the spraying of this fertiliser onto the golf course surface.

The fertilised areas consist solely of grass turf, therefore, vegetation interception is minimal (Cai et al. 2002). Non-manicured grass turf and densely vegetated areas, which are dispersed across the golf course, are referred to as non-fertilised areas (NFA) in this study. In order to prevent water logged conditions, the fertilised areas are mechanically aerated on a weekly basis. On-site golfing activity is primarily dependent upon the local climate and time of year. However, golfing activity increases during the summer months when the weather is generally drier and the days are longer. Additionally, application of the seaweed fertiliser is also at its maximum during the summer months. On average, 200 individuals visit the golf course on a daily basis, and a typical golfing session lasts 4.5 hours over 18 -holes. Most of the golfers are retired locals and visit the course on a daily basis. A conceptual model depicting the source of As contamination on-site, respective receptors, and potential pathways of exposure is shown in Fig. 1.

\subsection{Soil and groundwater sampling and analysis}


132 fairways, tee-off zones and putting greens), and NFA (i.e. densely vegetated areas and the rough)

133 (Fig. 2) using a stratified sampling technique. Nine soil cores $(0-24 \mathrm{~cm})$ were collected along three individual transects (A, B and C) located on a gradient that ran across both FA and NFA, in order to determine As concentrations at shallow depths. Each core was divided into four segments at depths of; 0-6 cm, 6-12 cm, 12-18 cm and 18-24 cm. Each transect was orientated from higher to lower elevation, with the first sampling point located up-gradient of the other two. The sampling points along the transects were located $10 \mathrm{~m}$ apart. This method was repeated along the three transects to identify whether leaching is occurring across the golf course. All sampling locations were georeferenced with a GPS unit. Duplicates were collected from every $5^{\text {th }}$ sampling location for data quality purposes. Soil samples were analysed for tAs by ICP-OES after microwave digestion in $10 \mathrm{ml}$ of $\mathrm{HNO}_{3}$ for 15 minutes, followed by filtering through a $0.45 \mu \mathrm{m}$ filter. Calibration with reference samples and blanks, and replicate analysis for quality control were carried-out to ensure reliability of analytical data. Fifty soil samples were randomly selected for particle size analysis by a Malvern Particle Sizer, and categorised by percentage weight according to Wentworth (1922).

Three groundwater samples were collected from an on-site borehole fitted with a submersible pump. The pump was run prior to sampling to ensure that the water sample was taken directly from the aquifer, and that the oxygen concentration reached a stable value (Buschmann et al. 2007). Each groundwater sample was collected in an acid-washed $500 \mathrm{ml}$ glass bottle, which was rinsed with the groundwater thoroughly before sampling (Buschmann et al. 2007). Samples were acidified to a $\mathrm{pH}$ of less than 2 with $1 \%$ concentrated $\mathrm{HNO}_{3}$ (Signes et al. 2008) before analysis by ICP-OES.

\subsection{Spatial analysis using GIS}

Sampling locations were plotted within the study site, and a geochemical map depicting As distribution in surface soils was generated using a GIS software (ArcMap 10). Inverse distance weighting (IDW) was used to examine the distribution of As in the golf course surface soil, as it is a 
geographical interface (Lee et al. 2006; Zhou et al. 2007; Qiao et al. 2011; Appleton and Adlam 2012;

158 Chabukdhara and Nema 2013). Using ArcMap10, the geochemical map obtained was overlain with a

159 polygon depicting the outline of the golf course and $1 \mathrm{~m}$ interval elevation contours. IDW provided

160 the general expected distribution of As on the golf course (Fig. 2).

161

162

163

164

165

166

167

168

169

170

171

172

173

174

175

176

177

178

179

180

181

182

183

\subsection{Risk characterisation}

Table 2 describes the methodology used to characterise the potential on-site carcinogenic risk through the pathway of dermal absorption of As-contaminated soil. Field and laboratory analysis provided a range of values for the tAs concentration in golf course soils (C). Out of 80 questionnaires distributed to the golfers at the club, information regarding golfer's habits on the golf course was obtained from 42 closed questionnaire responses. The responses provided a range of values for the following input parameters (1) exposed body parts (SA), (2) daily contact frequency with grass and soil (EV), (3) yearly exposure frequency (EF), and (4) lifetime exposure duration (ED).Monte Carlo simulation was used to account for the natural uncertainty and variability within a risk assessment. The method derived a set of possible outputs for the site specific exposure parameters, described above, that were observed to have a range of values (Table 2). It was observed that a frequency plot of the exposure time was distributed normally with finite values of minimum and maximum expected exposure times $\left(t_{\min }\right.$ and $\left.t_{\max }\right)$. Following this observation, the normal distribution was approximated by a uniform distribution using the method outlined by Sen Gupta and Dutta (1990). Therefore, the relevant equations can be expressed as follows:

Exposure time $t_{i}$ is given by,

$$
f\left(t_{i}\right)=\left[1 /\left\{\sigma_{i} \sqrt{ }(2 \pi)\right\}\right] \exp \left[-\left(t_{i}-T_{i}\right) /\left(2 \sigma_{i}^{2}\right)\right]
$$

where the exposure time of the ith individual player is $t_{i}$ and the mean of the distribution and the standard deviation are given by $\mathrm{T}_{\mathrm{i}}$ and $\sigma_{\mathrm{i}}$, respectively.

By approximating the exposure time by a uniform distribution, the lower and upper exposure limits are set to the observed minimum and maximum values for the dermal contact with the soil. This approximation will give a more realistic exposure time history of any player i, within the set limits of $t_{\min }$ and $t_{\max }$. The approximation by a uniform distribution and the capping of the maximum 
and the minimum exposure times for any player ensure that unrealistic high and low values of exposure are eliminated from the set of random variates generated by the Monte Carlo simulation. The observed normal distribution and the uniform distribution used for the simulation have identical mean and variance values, such that:

$$
\begin{aligned}
& \mathrm{T}_{\mathrm{i}}=\left(\mathrm{t}_{\text {max }}+\mathrm{t}_{\text {min }}\right) / 2 \\
& \sigma_{=}\left(\mathrm{t}_{\text {max }}-\mathrm{t}_{\text {min }}\right) / 2 \sqrt{3} \\
& \mathrm{t}_{\text {max }}=\mathrm{T}_{\mathrm{i}}+\sigma \sqrt{3} \\
& \mathrm{t}_{\text {min }}=\mathrm{T}_{\mathrm{i}}-\sigma \sqrt{3} \\
& \mathrm{t}_{\mathrm{i}}=\mathrm{t}_{\text {max }}+\left(\mathrm{t}_{\text {max }}-\mathrm{t}_{\text {min }}\right) . \xi
\end{aligned}
$$

where, $t_{i}$ is the random dermal exposure time for the ith player and $\xi$ is a random number such that $0<\xi<1$.

Monte Carlo simulation was performed using the EasyFitXL add-in for Microsoft Office Excel 2007 and applied using the steps below:

i. Five hundred random number (RND\#) iterations for each exposure input parameter were generated using Microsoft Excel.

ii. A set of random variates (RND V) for the random variable $t_{i}$ were calculated based on the following equation;

$\mathrm{RND} \mathrm{V}=\mathrm{t}_{\max }+\left(\mathrm{t}_{\max }-\mathrm{t}_{\min }\right) \cdot \xi$

iii. The range of probable exposure input parameter values were then inputted into equation (ii) to provide the possible range of ADI for individual site users of the golf course.

Input parameter values based on published data were used for the remainder of the model input values (Table 2).

\subsection{Results and discussion}

\subsection{Distribution of As contamination on the golf course}

The tAs concentration of surface soil samples in the study site varied between 0.2 and 10.38 $\mathrm{mg} / \mathrm{kg}$, with a mean of $2.39 \pm 2.14 \mathrm{mg} / \mathrm{kg}(\mathrm{n}=248)$. This mean value is significantly lower than that 
observed by the former soil survey and does not exceed the $32 \mathrm{mg} / \mathrm{kg}$ threshold for As in UK domestic soils (Environment Agency 2009). Nevertheless, a seaweed fertiliser with As concentrations ranging between 43 and $92 \mathrm{mg} / \mathrm{kg}$ is applied to the soil three times a month. Arsenic is considered to be moderately mobile in sandy soils (Cai et al. 2002), implying that the contaminant is either migrating laterally or percolating into underlying groundwater at this study site. Taking the sample location in to account, a significant difference $(\mathrm{P}=3.62 \mathrm{E}-7)$ between mean As concentration in FA ( $\mathrm{n}=193)$ and NFA ( $\mathrm{n}=55)$ was observed on-site, 3.63 and $2.04 \mathrm{mg} / \mathrm{kg}$, respectively (Table 1$)$. Soil fractionation showed that the bulk of the FA soils comprised a sand particle size between 0.125 and 2 $\mathrm{mm}$, while the NFA consisted of a mixture of clay and silt sized particles between 0.00006 and 0.125 mm (Fig. 3). Although all soil samples contained some fraction of clays, silts and sands, samples collected from the FA were coarser in texture with a $70.7 \%$ sand size fraction. Also, most of these sands were in the form of medium sand (32.2\%). The NFA had a finer soil texture, where $75.3 \%$ of grains were characterised as clays and silts (28.4\% as clays) according to the Wentworth grain size classification system (Wentworth 1922). Statistical analysis showed a correlation between As concentration and sample location, where fine to coarse sands were negatively correlated with As, and clays to very fine sands were positively correlated with As. This implies that As prefers sorption to the finer-sized clay and silt particles, such as those found in NFA, compared to the coarser-sized sand particles found in FA. Transect analysis confirms this observation. There is a clear sequential increase in tAs concentration along transects $\mathrm{A}$ and $\mathrm{B}$, which run down-gradient from a FA to NFA, and a clear decrease in tAs concentration along transect $\mathrm{C}$ that runs down-gradient from a NFA to FA. This suggests that the As present in FA, as a result of seaweed fertiliser application, is mobile and subject to lateral transport as surface runoff. Generally, the IDW output supports these observations (Fig. 2). IDW also indicated a west to east orientation of increasing As concentration in surface soils. The results suggest lateral movement of As from the porous sandy fertilised greens and fairways to the compacted clayey textured soil of the NFA. The NFA primarily consists of clayey textured soils and organic matter. Arsenic is strongly adsorbed by fine grained clay particles (Cai et al. 2002; Camm et al. 2004; Feng et al. 2005), which restrict its mobility, resulting in greater tAs concentrations within clayey textured soils, such as those found in the NFA. 
Castlehouse et al. (2003) reported the fate of arsenosugars present in the sandy soil fertilised with seaweed in a coastal region. The analysis of the pore water in the fertlised soil showed DMA(V), $\mathrm{AS}(\mathrm{V})$ and $\mathrm{As}(\mathrm{III})$. Hence, the authors proposed the pathway: arsenosugars $\rightarrow \mathrm{DMA}(\mathrm{V}) \rightarrow \mathrm{As}(\mathrm{V}) \rightarrow$ As(III). Zeng et al. (2011) have reported the detailed pathway of degradation of arsenosugars to inorganic arsenic in sediments and groundwater, which supports the degradation hypothesis of Castlehouse et al. (2003).

However, Castlehouse et al. (2003) did not focus on relative adsorption or desorption of these arsenic species, to or from soil. Shimizu et al (2011a) have reported that MMA sorption rate is higher than DMA in soil. Al and Fe oxyhydroxides are the main adsorbents for MMA and DMA in the soil and the sorption capacity is proportional to the $\mathrm{Al}$ and $\mathrm{Fe}$ concentration. The authors found varying desorption rate from the soil, ranging from $77 \%$ in one day to $66 \%$ in 6 months. They also observed that the retention period of MMA and DMA as sorption complexes with Fe-oxyhydroxides of soil could be as high as one year during which these species react within the soil matrix to inorganic forms. The main reason for the variation in time scale for transformation of the organic species to inorganic species was the variation of $\mathrm{Al}$ and Fe concentration in the soil (Shimizu et al., 2011b). This observation explains why the application of arsenic bearing seaweed fertilisers can increase the soil arsenic level by 10 fold as reported by Castlehouse et al. (2003).

In order to examine the vertical transport of As on-site, three cores extending to the subsoil layer were collected along three individual transects. Due to the nature of the land use, deeper cores could not be sampled from the golf course. The results indicate increasing As concentration with depth (Table 1). Within these areas, the golf club aerates the surface of the soil to avoid waterlogging of the FA, which promote a favourable environment for the leaching of mobile As. The difference between the surface sample $(0-6 \mathrm{~cm})$ and the deepest sample $(0-24 \mathrm{~cm})$ was greatest when the core was collected from a FA, with differences ranging between 0.63 and $1.72 \mathrm{mg} / \mathrm{kg}$ in FA and 0.04 to $0.96 \mathrm{mg} / \mathrm{kg}$ in NFA. The concentration of As in the deepest sample taken at P9 for example, was approximately twice that of the surface sample (Table 1). This observation agrees with that of Cai et al., who found that As is mobile in golf course soils (Cai et al. 2002) and, As may be 
percolating downwards. This observation is supported by groundwater analysis of the on-site borehole, where two of the three samples collected were observed as having As concentration exceeding the WHO permissible standard for As in water used for domestic purposes $(10 \mu \mathrm{g} / \mathrm{L})$ (Smith et al. 2000), and a maximum As concentrations of $12.5 \mu \mathrm{g} / \mathrm{L}$ (Fig.1). It is not certain whether the elevated As content is attributed to the natural geology or the application of seaweed fertiliser. However, the groundwater underlying the golf course has between 3 and 12 times more As than that previously observed in surrounding groundwater; thus, it is likely that the presence of As is a result of seaweed fertiliser application and subsequent leaching at the study site, as previously observed in similar studies following MSMA application (Di Carlo and Fuentes 2000; Cai et al. 2002; Feng et al. 2005; Chen et al. 2006). The results suggest, therefore, that As can be transported vertically in a golf course profile following application of a seaweed fertiliser. Over the past few decades, elevated concentrations of As have been observed in groundwater underlying golf course greens amended with As-bearing fertilisers, pesticides and herbicides (FPHs), and this has become a significant topic of scientific and environmental health interest (Cai et al. 2002; Feng et al. 2005; Chen et al. 2006; Pichler et al. 2008). As previously discussed, the fertilised areas consist primarily of sand, which have a high silica content (Cai et al. 2002; Bary et al. 2005; Chen et al. 2006). Arsenic is not easily bound to silica, therefore, this type of environment can result in high leaching rates (Feng et al. 2005). Feng et al. observed that golf course soils with high sand content and low clay content were favourable for As mobility and subsequent leaching following application of an As-bearing FPH, whereas soils with a higher clay content prevented the leaching of As, reducing the concentration of As in underlying groundwater (Feng et al. 2005). Although the As-containing agricultural products under investigation in these studies are prohibited in the UK, observation of their behaviour in the environment may be applied to that of seaweed fertilisers, as they are primarily present in organoarsenical form (Feng et al. 2005). Also, those arsenical FPHs discussed above are only applied two to three times a year (Feng et al. 2005), whereas the seaweed fertiliser in this study is applied three times per month (a 12-fold increase). Therefore, this practice may cause a greater legacy of contamination. 

for domestic soils (i.e. As $\geq 32 \mathrm{mg} / \mathrm{kg}$ ) (DEFRA and EA 2004), analysis has shown that there is a positive relationship between As content and fine particle size, which are the fractions that readily adhere to the skin (Ljung et al. 2006) and thus, can cross the dermis absorption barrier (Lim et al. 2008). Within a golf course context, golfers can come in to dermal contact with the soil and golf turf through two primary scenarios; frequent non-gloved hand to turf and ball contact on FA and NFA and leg to grass/soil contact when the golfer is looking for a ball in the rough whilst wearing shorts. The latter would be more typical of novice golfers and in the summer months. Although the authors acknowledge inhalation of fine dust particles as pathway for As exposure, the lesser studied potential risk via dermal absorption of As in a golf course scenario was examined, where seaweed fertiliser was applied. The purpose of this exercise was to establish a method that could be used in other environments where seaweed fertiliser is applied, such as rugby and soccer pitches. On these types of sports greens, the frequency and duration of contact and the degree of exposure is significantly greater for the player than that of golfers. The carcinogenic risk of As exposure, through the pathway of dermal absorption with contaminated soil, is based on the assumption that As is in a form that may cause cancer (i.e. in an inorganic form) (Gerba 2000; Qiao et al. 2011). Although the form of As present within the soil at the study site is unknown, a worst case scenario will be assumed as it has been shown that the application of organoarsenicals on a golf course environment can initiate reduction processes that produce several species of As, including inorganic forms (Cai et al. 2002; Feng et al. 2005). Therefore, inorganic As may be present in surface soils on-site. A deterministic risk method was used to calculate the best and worst case carcinogenic risk value for golfing activities, based on the range of risk input parameter values (Table 2). This value was then compared to a published reference value for As to determine whether the risk is acceptable or not (U.S. 316 Environmental Protection Agency 2004; Rose et al. 2007; Mondal and Polya 2008; Qiao et al. 2011).

317 There is some discrepancy regarding the acceptable risk value for As exposure. The USEPA suggests 318 that any risk value greater than $10^{-6}$ is unacceptable (U.S. Environmental Protection Agency 2004). 
319 However, other studies use an acceptable risk range of $10^{-6}$ to $10^{-4}$ for similar environmental health 320 studies (Phaneuf et al. 1999; Zakharova et al. 2002; Lim et al. 2008; Mondal and Polya 2008; Liang et al. 2011; Qiao et al. 2011; Hu et al. 2012), which indicate that within a population of one million, it is acceptable for one out of every 10,000 people die from cancer induced from exposure to As (Lim et al. 2008). The lack of an evidence based acceptable risk threshold is indicative of the lack of knowledge surrounding As exposure across a wide range of environmental contexts. The high degree of ambiguity has created a scenario where it is difficult to ascertain whether a particular exposure scenario is hazardous or not. With respect to liquid seaweed fertilisers, the scenario has occurred through uncertainty regarding the toxicity of organic As forms, the lack of epidemiological data on the potential health effects of organic As, and the lack of cohesive legislation regarding the use of As containing natural fertilisers.

In this study, the calculated risk of As exposure via dermal absorption was in the range of $2.20 \times 10^{-9}$ to $2.75 \times 10^{-4}$. With respect to the USEPA threshold, the maximum risk value observed at this site exceeds the threshold by two orders of magnitude, indicating that the risk of As exposure to golfers at this study site is unacceptable. With regards to the risk range used in similar studies, the results of the risk characterisation indicate that the maximum soil As concentrations and exposure home gardens. Within the scenarios, exposure time, frequency of contact with soil and the fraction of body parts exposed may be significantly greater than that on a golf course. For example, within the sport of rugby, the exposed body parts and the frequency of contact between the soil and the skin (i.e. during scrums and tackles) would be significantly greater. Also, within these contexts, the soils on these types of sporting greens primarily have finer textures consisting of clays and silts. Therefore, they differ greatly from golf course soil. The As applied to the soil, via seaweed fertiliser application, 
scenario where the risk of dermal absorption of As is greater than that observed at this private golf course.

\subsection{Conclusions and Recommendations}

The growing concern and publicity regarding As risk to human health, coupled with the

351 scarcity of published information on As-containing seaweed fertilisers, is the driving force behind this study. The study found that application of seaweed fertiliser to golf course soils does not result in As concentrations that exceed the UK threshold for As in domestic soils. Although UK limits are not exceeded, it is still important to acknowledge the contact time and frequency of use between site users and the soil in order to ascertain whether a risk is present. The results showed that the USEPA acceptable risk level for dermal contact with As through a soil pathway was exceeded for this particular study, despite low concentrations of As present in surface soils. In scenarios of more frequent physical contact with soil, such as during rugby and soccer activities, the risk of exposure may also be greater.

The results of this study revealed that As is present at concentrations of potential concern in groundwater underlying the golf course. Although the groundwater is not used for domestic purposes, the results of analysis indicate that there is a risk of groundwater contamination following seaweed fertiliser application in a golf course setting. The greatest As concentration in the groundwater samples was $12.5 \mu \mathrm{g} / \mathrm{L}$, which exceeds the WHO guideline for As in drinking water. This indicates that As contaminated seaweed fertiliser application to sandy golf soils can result in groundwater contamination. The use of As-containing seaweed fertiliser, therefore, may contribute to the arsenic burden of the environment and as such increase the probability of human exposure to As (Chen et al. 2006).

This is, to our knowledge, the first study concerned with identifying the presence of As on golf course soils following seaweed fertiliser application. This study suggests that seaweed fertilisers should be used with caution, especially in areas that are underlain by a groundwater source, and in 
environments where dermal contact with the soil is common (i.e. rugby pitches). This is a pilot study; therefore, further research is required across the various environments where seaweed fertilisers may be used. The study also recommends that a speciation study be conducted within these various environments, and an in depth column study be conducted to assess the fate and transport of As within the various profiles where seaweed fertiliser is applied.

\section{Acknowledgement}

We thank Micky O’Neill for his invaluable help during the field work phase of this study.

\section{References}

Abernathy CO, Liu YP, Longfellow D, Aposhian H V, Beck B, Fowler B, et al. Arsenic: health effects, mechanisms of actions, and research issues. Environ Health Perspect [Internet]. $1999 \mathrm{Jul}$ [cited 2013 Feb 13];107(7):593-7. Available from:

http://www.pubmedcentral.nih.gov/articlerender.fcgi?artid=1566656\&tool=pmcentrez\&renderty $\mathrm{pe}=\mathrm{abstract}$

Agency for Toxic Substances and Disease Registry. ATSDR Case studies in environmental medicine. 2011.

Almela C, Clemente MJ, Vélez D, Montoro R. Total arsenic, inorganic arsenic, lead and cadmium contents in edible seaweed sold in Spain. Food Chem Toxicol [Internet]. 2006 Nov [cited 2013 Feb 7];44(11):1901-8. Available from: http://www.ncbi.nlm.nih.gov/pubmed/16901603

Andrewes P, Demarini DM, Funasaka K, Wallace K, Lai VWM, Sun H, et al. Do arsenosugars pose a risk to human health? The comparative toxicities of a trivalent and pentavalent arsenosugar. Environ Sci Technol [Internet]. 2004 Aug 1;38(15):4140-8. Available from: http://www.ncbi.nlm.nih.gov/pubmed/15352453

Appleton JD, Adlam KAM. Geogenic control on soil chemistry in urban areas: A novel method for urban geochemical mapping using parent material classified data. Appl Geochemistry [Internet]. 2012 Jan [cited 2013 Mar 23];27(1):161-70. Available from: http://dx.doi.org/10.1016/j.apgeochem.2011.10.001

Arnold, L. L., Eldan, M., Abraham, N., Van Gemert, M, Cohen, S. M., Dimethylarsinic acid: Results of chronic toxicity/oncogenecity studies in F344 rats and in B6C3F1 mice, Toxicology, 223, 2006, pp. 82-100. 
Ascar L, Ahumada I, Richter P. Influence of redox potential (Eh) on the availability of arsenic species in soils and soils amended with biosolid. Chemosphere [Internet]. 2008 Aug [cited $2013 \mathrm{Feb}$ 7];72(10):1548-52. Available from: http://www.ncbi.nlm.nih.gov/pubmed/18550147

Bary F, Gange AC, Crane M, Hagley KJ. Fungicide levels and arbuscular mycorrhizal fungi in golf putting greens. J Appl Ecol [Internet]. 2005 Feb [cited 2013 Feb 19];42(1):171-80. Available from: http://doi.wiley.com/10.1111/j.1365-2664.2004.00989.x

Buschmann J, Berg M, Stengel C, Sampson ML. Arsenic and manganese contamination of drinking water resources in Cambodia: coincidence of risk areas with low relief topography. Environ Sci Technol [Internet]. 2007 Apr 1;41(7):2146-52. Available from: http://www.ncbi.nlm.nih.gov/pubmed/17438755

Cai Y, Cabrera JC, Georgiadis M, Jayachandran K. Assessment of arsenic mobility in the soils of some golf courses in South Florida. Sci Total Environ [Internet]. 2002 May 27;291(1-3):123-34. Available from: http://www.ncbi.nlm.nih.gov/pubmed/12150432

Camm GS, Glass HJ, Bryce DW, Butcher AR. Characterisation of a mining-related arseniccontaminated site, Cornwall, UK. J Geochemical Explor [Internet]. 2004 Apr [cited $2013 \mathrm{Mar}$ 11];82(1-3):1-15. Available from: http://dx.doi.org/10.1016/j.gexplo.2004.01.004

Di Carlo GW, Fuentes HR. POTENTIAL TRANSPORT OF THE HERBICIDE MSMA AND ARSENATE (+5) FROM GOLF COURSES TO GROUNDWATER IN SOUTHEASTERN FLORIDA. Proc WEFTEC, Annu Conf Expo Water Qual Wastewater Treat [Internet]. Anaheim, CA: Water Environment Federation; 2000 [cited 2013 Feb 19]. p. 2938-65. Available from: http://qub.library.ingentaconnect.com/content/wef/wefproc/2000/00002000/00000012/art00041

Castlehouse H, Smith C, Raab A, Deacon C, Meharg A, Feldmann J. Biotransformation and accumulation of arsenic in soil amended with seaweed. Environ Sci Technol [Internet]. 2003 Mar 1;37(5):951-7. Available from: http://www.ncbi.nlm.nih.gov/pubmed/12666926

Caumette G, Ouypornkochagorn S, Scrimgeour CM, Raab A, Feldmann J. Monitoring the arsenic and iodine exposure of seaweed-eating North Ronaldsay sheep from the gestational and suckling periods to adulthood by using horns as a dietary archive. Environ Sci Technol [Internet]. 2007 Apr 15;41(8):2673-9. Available from: http://www.ncbi.nlm.nih.gov/pubmed/17533823

Chabukdhara M, Nema AK. Heavy metals assessment in urban soil around industrial clusters in Ghaziabad, India: probabilistic health risk approach. Ecotoxicol Environ Saf [Internet]. 2013 Jan [cited 2013 Mar 21];87(null):57-64. Available from: http://dx.doi.org/10.1016/j.ecoenv.2012.08.032

Chen Z, Cai Y, Solo-Gabriele H, Snyder GH, Cisar JL. Interactions of Arsenic and the Dissolved Substances Derived from Turf Soils. Environ Sci Technol [Internet]. American Chemical Society; 2006 Aug [cited 2013 Feb 19];40(15):4659-65. Available from: http://dx.doi.org/10.1021/es060619m

Cohen, S. M., Arnold, L.L., Uziolgyi, E., Cano, M., St John, M., Yamamoto, S., Lu, X., Le, X. C., Possible Role of dimethylarsinous acid in dimethyl arsenic acid-induced urothelial toxicity and regeneration in the rat, Chem. Res. Toxicology, 15 (9), 2002, pp. 1150-1157.

DEFRA, EA. Soil Guideline Values for Arsenic Contamination. 2004. 
Feng M, Schrlau JE, Synder R, Synder GH, Chen M, Cisas JL, et al. Arsenic transport and transformation associated with MSMA application on a golf course green. J Agric Food Chem [Internet]. 2005 Mar 22;53:3556-62. Available from: http://www.ncbi.nlm.nih.gov/pubmed/16536631

Gerba CP. Risk assessment. In: Environmental Microbiology. Gerba CP, Maier RM, Pepper IL, editors. London: Academic Press; 2000. p. 557-71.

Halder D, Bhowmick S, Biswas A, Chatterjee D, Nriagu J, Guha Mazumder DN, et al. Risk of arsenic exposure from drinking water and dietary components: implications for risk management in rural bengal. Environ Sci Technol [Internet]. 2013 Jan 15;47(2):1120-7. Available from: http://www.ncbi.nlm.nih.gov/pubmed/23198808

Hansen HR, Raab A, Francesconi K, Feldmann I. Metabolism of arsenic by sheep chronically exposed to arsenosugars as a normal part of their diet. 1. Quantitative intake, uptake, and excretion. Environ Sci Technol [Internet]. 2003 Mar 1;37(5):845-51. Available from: http://www.ncbi.nlm.nih.gov/pubmed/12666911

Hirano, S., Kobayashi, Y, Cui, X., Kanno, S., Hayakawa, T., Shraim, A., The accumulation and toxicity of methylated arsenicals in endothelial cells: important roles of thiol compounds, Toxicology and Applied Pharmacology, Vol 198, 2004, pp. 458-467

Hu X, Zhang Y, Ding Z, Wang T, Lian H, Sun Y, et al. Bioaccessibility and health risk of arsenic and heavy metals (Cd, Co, Cr, Cu, Ni, Pb, Zn and Mn) in TSP and PM2.5 in Nanjing, China. Atmos Environ [Internet]. 2012 Sep [cited 2013 Feb 13];57(null):146-52. Available from: http://dx.doi.org/10.1016/j.atmosenv.2012.04.056

Joint FAO/WHO Expert Committee on Food additives. Evaluation of certain contaminants in food. 2011.

Le, X. C., Speciation of Arsenic in Water and Biological Matrices, AWWA publication, Denver, USA, p 75, 2001, ISBN: 1-58321-085-7

Lee CS-L, Li X, Shi W, Cheung SC, Thornton I. Metal contamination in urban, suburban, and country park soils of Hong Kong: a study based on GIS and multivariate statistics. Sci Total Environ [Internet]. 2006 Mar 1 [cited 2013 Jan 30];356(1-3):45-61. Available from: http://www.ncbi.nlm.nih.gov/pubmed/15913711

Leermakers, M., Baeyens, W, De Gieter, M, Smelds, B., Meert, C., De Bisschop, H. C., Morabito, R. , Queviller, P, Trends in Analytical Chemistry, Vol 25( 1), 2006, pp 1-10.

Liang C-P, Liu C-W, Jang C-S, Wang S-W, Lee J-J. Assessing and managing the health risk due to ingestion of inorganic arsenic from fish and shellfish farmed in blackfoot disease areas for general Taiwanese. J Hazard Mater [Internet]. 2011 Feb 15 [cited 2013 Mar 21];186(1):622-8. Available from: http://dx.doi.org/10.1016/j.jhazmat.2010.11.042

Lim H-S, Lee J-S, Chon H-T, Sager M. Heavy metal contamination and health risk assessment in the vicinity of the abandoned Songcheon $\mathrm{Au}-\mathrm{Ag}$ mine in Korea. J Geochemical Explor [Internet]. 2008 Feb [cited 2013 Mar 21];96(2-3):223-30. Available from: http://dx.doi.org/10.1016/j.gexplo.2007.04.008 
Ljung K, Selinus O, Otabbong E, Berglund M. Metal and arsenic distribution in soil particle sizes relevant to soil ingestion by children. Appl Geochemistry [Internet]. 2006 Sep [cited 2013 Mar 6];21(9):1613-24. Available from: http://dx.doi.org/10.1016/j.apgeochem.2006.05.005

Macedo SM, de Jesus RM, Garcia KS, Hatje V, Queiroz AFDS, Ferreira SLC. Determination of total arsenic and arsenic (III) in phosphate fertilizers and phosphate rocks by HG-AAS after multivariate optimization based on Box-Behnken design. Talanta [Internet]. 2009 Dec 15 [cited 2013 Feb 7];80(2):974-9. Available from: http://www.ncbi.nlm.nih.gov/pubmed/19836581

Mondal D, Polya D. Rice is a major exposure route for arsenic in Chakdaha block, Nadia district, West Bengal, India: A probabilistic risk assessment. Appl Geochemistry [Internet]. Elsevier Ltd; 2008 Nov [cited 2013 Feb 7];23(11):2987-98. Available from: http://linkinghub.elsevier.com/retrieve/pii/S0883292708002345

Phaneuf D, Côté I, Dumas P, Ferron LA, LeBlanc A. Evaluation of the contamination of marine algae (Seaweed) from the St. Lawrence River and likely to be consumed by humans. Environ Res [Internet]. 1999 Feb [cited 2013 Mar 14];80(2 Pt 2):S175-S182. Available from: http://dx.doi.org/10.1006/enrs.1998.3915

Pichler T, Brinkmann R, Scarzella GI. Arsenic abundance and variation in golf course lakes. Sci Total Environ [Internet]. 2008 May 15 [cited $2013 \mathrm{Feb}$ 7];394(2-3):313-20. Available from: http://www.ncbi.nlm.nih.gov/pubmed/18314159

Qiao M, Cai C, Huang Y, Liu Y, Lin A, Zheng Y. Characterization of soil heavy metal contamination and potential health risk in metropolitan region of northern China. Environ Monit Assess [Internet]. 2011 Jan [cited $2013 \mathrm{Feb}$ 7];172(1-4):353-65. Available from: http://www.ncbi.nlm.nih.gov/pubmed/20135216

Rahman MA, Rahman MM, Hasegawa H. Arsenic-induced straighthead: an impending threat to sustainable rice production in South and South-East Asia! Bull Environ Contam Toxicol [Internet]. 2012 Mar [cited 2013 Feb 7];88(3):311-5. Available from: http://www.ncbi.nlm.nih.gov/pubmed/22139332

Rose M, Lewis J, Langford N, Baxter M, Origgi S, Barber M, et al. Arsenic in seaweed--forms, concentration and dietary exposure. Food Chem Toxicol [Internet]. 2007 Jul [cited 2013 Feb 7];45(7):1263-7. Available from: http://www.ncbi.nlm.nih.gov/pubmed/17336439

Signes A, Mitra K, Burlo F, Carbonell-Barrachina AA. Effect of cooking method and rice type on arsenic concentration in cooked rice and the estimation of arsenic dietary intake in a rural village in West Bengal, India. Food Addit Contam Part A Chem Anal Control Expo Risk Assess [Internet]. 2008 Nov [cited $2013 \mathrm{Feb} 7$ ];25(11):1345-52. Available from: http://www.ncbi.nlm.nih.gov/pubmed/19680842

Shimizu, M., Arai, Y., Sparks D. L. Multiscale Assessment of methylarsenic reactivity in soil. 1. Sorption and Desorption on soils, Environ Sci Technol, 2011a, 45 (10), pp 4293-4299.

Shimizu, M., Arai, Y., Sparks D. L. Multiscale Assessment of methylarsenic reactivity in soil. 2. Distribution and Speciation in soil, Environ Sci Technol, 2011 b, 45 (10), pp 4300-4306.

Smith AH, Lingas EO, Rahman M. Contamination of drinking-water by arsenic in Bangladesh: a public health emergency. Bull World Health Organ [Internet]. World Health Organization; 2000 Jan [cited $2013 \mathrm{Feb} 24] ; 78(9): 1093-103$. Available from: /pmc/articles/PMC2560840/?report=abstract 
Smith AH, Lopipero PA, Bates MN, Steinmaus CM. Public health. Arsenic epidemiology and drinking water standards. Science [Internet]. 2002 Jun 21 [cited 2013 Feb 13];296(5576):21456. Available from: http://www.sciencemag.org/content/296/5576/2145.short

U.S. Environmental Protection Agency. Special report on ingested inorganic arsenic. Skin cancer; Nutritional essentiality. 1988 p. EPA/625/3-87/013.

U.S. Environmental Protection Agency. Risk assessment guidance for superfund volume I : Human health evaluation manual (Part E, supplemental guidance for dermal risk assessment). 2004.

U.S. Environmental Protection Agency. Guidelines for Carcinogen Risk Assessment. 2005.

Wentworth CK. A Scale of Grade and Class Terms for Clastic Sediments. J Geol [Internet]. 1922;30(5):377-92. Available from: http://www.jstor.org/stable/30063207

Zakharova T, Tatàno F, Menshikov V. Health Cancer Risk Assessment for Arsenic Exposure in Potentially Contaminated Areas by Fertilizer Plants: A Possible Regulatory Approach Applied to a Case Study in Moscow Region-Russia. Regul Toxicol Pharmacol [Internet]. 2002 Aug [cited 2013 Feb 13];36(1):22-33. Available from: http://dx.doi.org/10.1006/rtph.2002.1561

Zhou F, Guo H, Hao Z. Spatial distribution of heavy metals in Hong Kong's marine sediments and their human impacts: a GIS-based chemometric approach. Mar Pollut Bull [Internet]. 2007 Sep [cited 2013 Feb 7];54(9):1372-84. Available from: http://www.ncbi.nlm.nih.gov/pubmed/17624377

Zeng, X., He, Q, Bai, L., Li, L., Su, S., The arsenic speciation transformation in artificially arsenic contaminated fluvo-aquatic soil (Beijing, China), Plant Soil Environment, 57 (3), 2011, pp 108114.

\begin{tabular}{|c|c|c|c|c|c|c|c|c|c|}
\hline & & \multicolumn{8}{|c|}{ Surface Soil Samples } \\
\hline & & $\mathrm{n}$ (no of samples) & \multicolumn{2}{|l|}{ Mean $(\mathrm{mg} / \mathrm{kg})$} & \multicolumn{2}{|l|}{ Std error (mg/kg) } & $\operatorname{Min}(\mathrm{mg} / \mathrm{kg})$ & \multicolumn{2}{|r|}{$\operatorname{Max}(\mathrm{mg} / \mathrm{kg})$} \\
\hline \multicolumn{2}{|l|}{ FA (all) } & 193 & \multicolumn{2}{|l|}{2.04} & \multicolumn{2}{|l|}{0.14} & 0.2 & \multicolumn{2}{|r|}{10.38} \\
\hline \multicolumn{2}{|l|}{ Fairways } & 139 & \multicolumn{2}{|l|}{2.38} & \multicolumn{2}{|l|}{0.18} & 0.2 & \multicolumn{2}{|r|}{10.38} \\
\hline \multicolumn{2}{|c|}{ Putting greens } & 54 & \multicolumn{2}{|l|}{1.36} & \multicolumn{2}{|l|}{0.17} & 0.2 & \multicolumn{2}{|r|}{5.69} \\
\hline \multicolumn{2}{|l|}{ NFA (all) } & 55 & \multicolumn{2}{|l|}{3.63} & \multicolumn{2}{|l|}{0.34} & 0.2 & \multicolumn{2}{|r|}{8.97} \\
\hline \multicolumn{2}{|l|}{ The rough } & 23 & \multicolumn{2}{|l|}{3.37} & \multicolumn{2}{|l|}{0.57} & 0.2 & \multicolumn{2}{|r|}{8.97} \\
\hline \multicolumn{2}{|c|}{ Dense vegetation } & 32 & \multicolumn{2}{|l|}{3.81} & \multicolumn{2}{|l|}{0.41} & 0.2 & \multicolumn{2}{|r|}{7.77} \\
\hline \multicolumn{2}{|c|}{ Whole golf course } & 248 & \multicolumn{2}{|l|}{2.39} & \multicolumn{2}{|l|}{0.14} & 0.2 & \multicolumn{2}{|r|}{10.38} \\
\hline \multicolumn{10}{|c|}{ Core Soil Samples } \\
\hline Depth, cm & \multicolumn{3}{|c|}{ A (FA to NFA) $\mathrm{mg} / \mathrm{kg}$} & \multicolumn{3}{|c|}{$\mathrm{B}$ (FA to NFA) $\mathrm{mg} / \mathrm{kg}$} & & (NFA & FA) $\mathrm{mg} / \mathrm{kg}$ \\
\hline $0-6$ & 3.94 & 6.79 & 8.97 & 2.11 & 2.67 & 4.14 & 5.13 & 4.75 & 1.93 \\
\hline 6-12 & 3.34 & 4.88 & 8.96 & 2.37 & 2.71 & 4.36 & 5.01 & 4.96 & 2.14 \\
\hline $12-18$ & 4.00 & 5.95 & 8.97 & 2.98 & 3.01 & 4.78 & 5.56 & 5.18 & 4.36 \\
\hline $18-24$ & 4.57 & 6.94 & 9.01 & 3.25 & 3.96 & 5.10 & 5.82 & 5.49 & 3.65 \\
\hline
\end{tabular}


Table 2. Risk Characterisation Methodology

References for equation: (1) USEPA (2004) and Qiao et al. (2011), (2) USEPA (2004). ' SA was calculated by adding the body-part specific SA calculations for adults as described by USEPA (2004). The lower range body parts included; forearms, hands and neck, whilst the upper range also included lower legs.

$$
\text { Risk }=\mathrm{ADI} \times \mathrm{SF}
$$

Where $\mathrm{ADI}=\underline{\mathrm{C} \times \mathrm{AF} \times \mathrm{ABS} \times \mathrm{CF} \times \mathrm{SA} \times \mathrm{EV} \times \mathrm{EF} \times \mathrm{ED}}$ BW x AT

\begin{tabular}{|c|c|c|c|}
\hline $\begin{array}{l}\text { Exposure } \\
\text { parameter }\end{array}$ & Description & Value & Source \\
\hline Risk & $\begin{array}{l}\text { The probability of an } \\
\text { individual developing cancer } \\
\text { over a lifetime }\end{array}$ & & Site specific \\
\hline $\begin{array}{c}\mathrm{ADI} \\
\left(\mathrm{mgkg}^{-1} \text {-day }\right)\end{array}$ & Absorbed Daily Intake & & Site specific \\
\hline $\begin{array}{c}\mathrm{SF} \\
\left(\mathrm{mgkg}^{-1} \text {-day }\right)^{-1}\end{array}$ & Absorbed Cancer Slope Factor & 3.66 & RAIS (2013) \\
\hline$\underset{\left(\mathrm{mgkg}^{-1}\right)}{\mathrm{C}}$ & Concentration of As in soil & $\begin{array}{l}0.2- \\
10.38\end{array}$ & Site specific \\
\hline $\begin{array}{c}\mathrm{AF} \\
\left(\mathrm{mgcm}^{-2}\right)\end{array}$ & $\begin{array}{l}\text { Resident Soil Adherence } \\
\text { Factor }\end{array}$ & $0.07-0.1$ & $\begin{array}{l}\text { USEPA (2004) } \\
\text { Qiao et al. (2011) }\end{array}$ \\
\hline $\mathrm{ABS}$ & Absorption Factor for As & 0.03 & USEPA (2004) \\
\hline$\underset{\left(\mathrm{kgmg}^{-1}\right)}{\mathrm{CF}}$ & Conversion Factor & $10^{-6}$ & USEPA (2004) \\
\hline $\begin{array}{l}\mathrm{SA}^{1} \\
\left(\mathrm{~cm}^{2}\right)\end{array}$ & $\begin{array}{l}\text { Available Exposed Surface } \\
\text { Area }\end{array}$ & $\begin{array}{c}2733- \\
5293\end{array}$ & $\begin{array}{l}\text { Site specific } \\
\text { USEPA (2004) }\end{array}$ \\
\hline $\mathrm{EV}$ (eventsday ${ }^{-1}$ ) & Event Frequency & $18-108$ & Site specific \\
\hline $\mathrm{EF}\left(\right.$ daysyr $\left.^{1}\right)$ & Exposure Frequency & $0-260$ & Site specific \\
\hline $\mathrm{ED}(\mathrm{yrs})$ & Exposure Duration & $1-29$ & Site specific \\
\hline $\mathrm{BW}(\mathrm{kg})$ & Body Weight & 70 & $\begin{array}{l}\text { USEPA (2004) } \\
\text { Qiao et al. (2011) }\end{array}$ \\
\hline $\mathrm{AT}\left(\right.$ daysyr $\left.^{-1}\right)$ & $\begin{array}{l}\text { Averaging Lifetime for } \\
\text { Carcinogens }\end{array}$ & 25550 & $\operatorname{ATSDR}(2005)$ \\
\hline
\end{tabular}




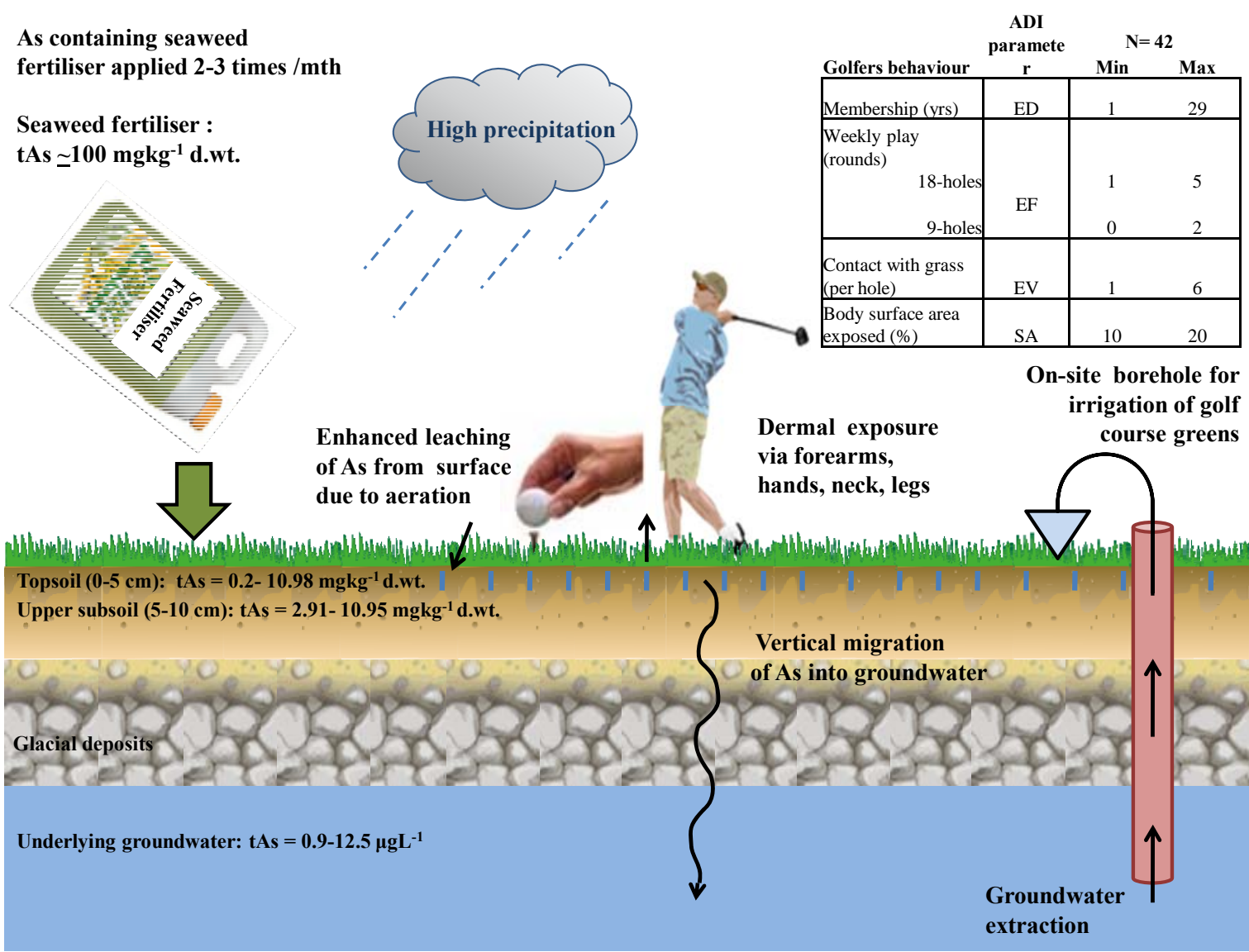

Fig. 1. Refined conceptual model identifying the two pathways of concern with respect to As contamination; dermal absorption via contact with soil and groundwater contamination via leaching. ${ }^{1}$ Golfing statistics are based on 42 closed questionnaire responses acquired out of 80 from members of the private golf club under study. 


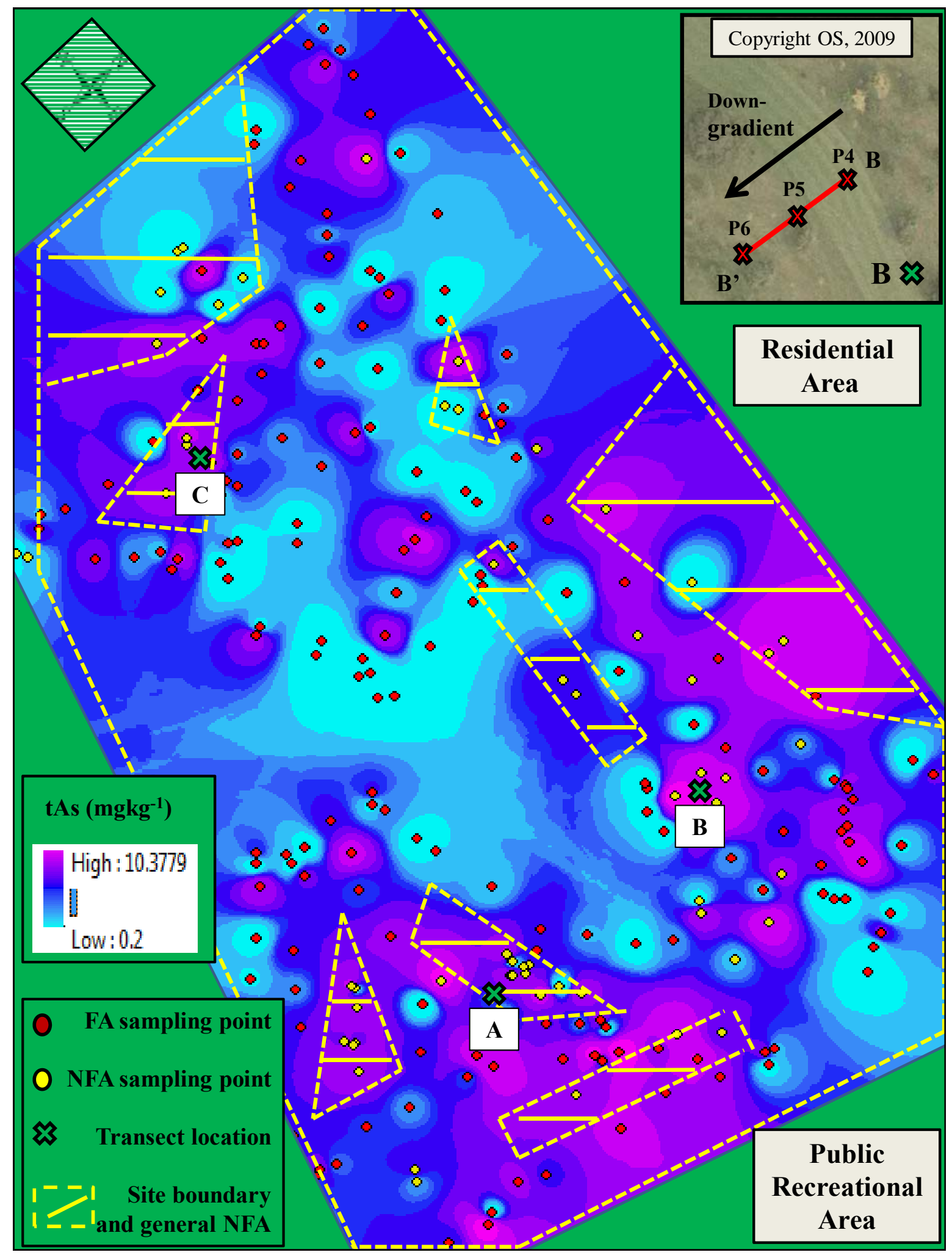

Fig. 2. Geochemical map of tAs concentration in the surface soils by IDW. Sampling locations, type of grass cover and an example of transect orientation are also provided. 


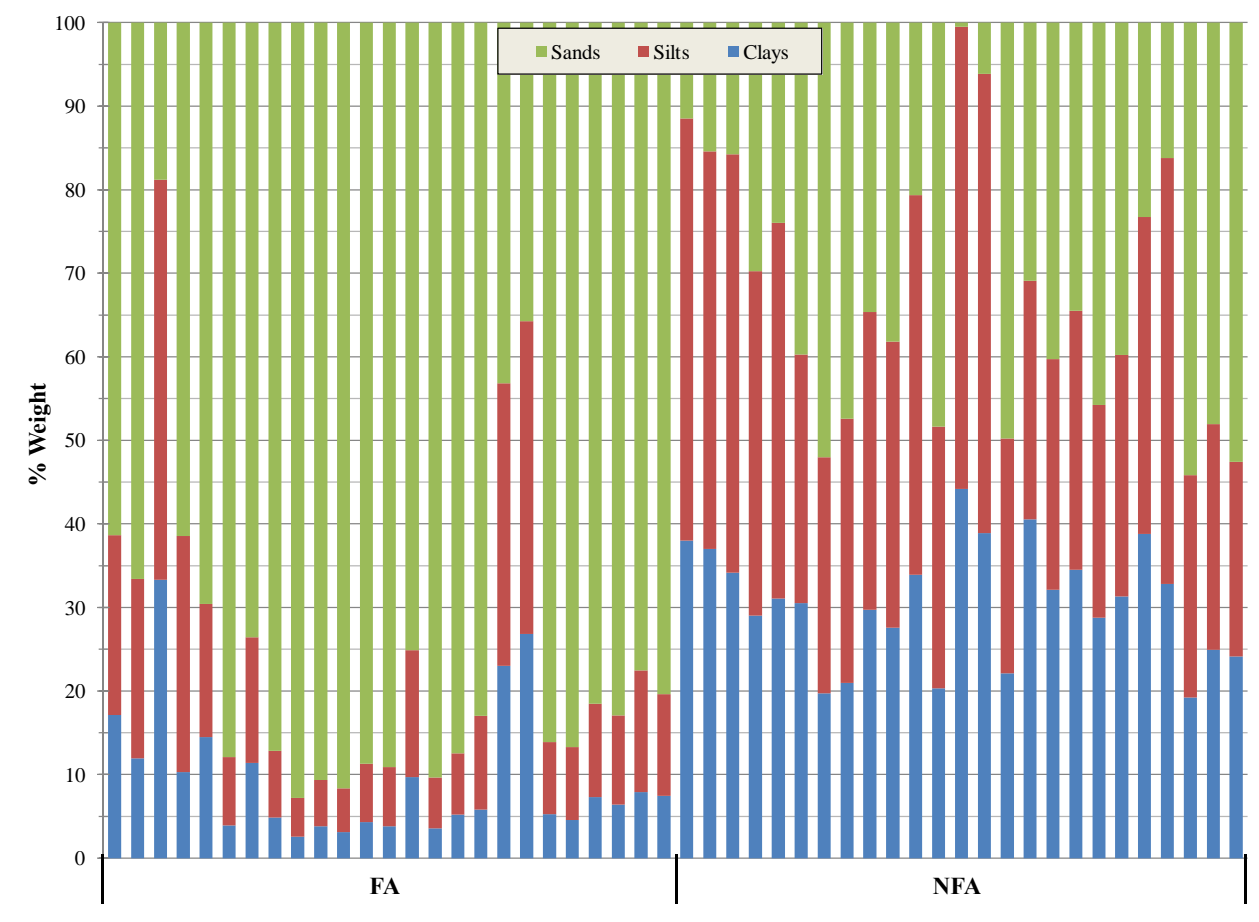

Fig. 3. Soil particle size distribution (\%) in 50 samples collected from fertilised areas (FA) and nonfertilised areas (NFA) at the study site. 